\title{
Southern rice black-streaked dwarf virus Alters Insect Vectors' Host Orientation Preferences to Enhance Spread and Increase Rice ragged stunt virus Co-Infection
}

\author{
Han Wang, Donglin Xu, Lingling Pu, and Guohui Zhou
}

Guangdong Province Key Laboratory of Microbial Signals and Disease Control, College of Natural Resources and Environment, South China Agricultural University, Guangzhou, Guangdong 510642, China. Accepted for publication 3 September 2013.

\begin{abstract}
Wang, H., Xu, D., Pu, L., and Zhou, G. 2014. Southern rice blackstreaked dwarf virus alters insect vectors' host orientation preferences to enhance spread and increase Rice ragged stunt virus co-infection. Phytopathology 104:196-201.

In recent years, Southern rice black-streaked dwarf virus (SRBSDV), a tentative species in the genus Fijivirus (family Reoviridae), has spread rapidly and caused serious rice losses in eastern and southeastern Asia. With this virus spread, Rice ragged stunt virus (RRSV, genus Oryzavirus, family Reoviridae) became more common in southern China, usually in co-infection with the former. SRBSDV and RRSV are transmitted by two

using a Y-shape olfactometer-based device, we tested the host preference of three types of macropterous WBPH adults for healthy or SRBSDVinfected rice plants. The results showed that virus-free WBPHs significantly preferred infected rice plants to healthy plants, whereas both the viruliferous and nonviruliferous WBPHs preferred healthy plants to infected plants. In additional tests, we found that the BPHs significantly preferred healthy plants when they were virus free, whereas RRSVcarrying BPHs preferred SRBSDV-infected rice plants. From these findings, we propose that plant viruses may alter host selection preference of vectors to enhance their spread and that of insects vectoring another virus to result in co-infection with more than one virus.
\end{abstract} different species of planthoppers, white-backed planthopper (WBPH, Sogatella furcifera) and brown planthopper (BPH, Nilaparvata lugens), respectively, in a persistent, circulative, propagative manner. In this study,
Additional keywords: virus-plant-vector interaction.
Southern rice black-streaked dwarf virus (SRBSDV), a tentative species in the genus Fijivirus (family Reoviridae), was first found in 2001 in Guangdong Province, China (27,32,33). The virus can infect rice, maize, and other gramineous plants, and is limited to the phloem of host plants. It has rapidly spread among East and Southeast Asian countries and caused serious damage to rice production in recent years $(7,13,32)$. Previous studies showed that the virus can be efficiently transmitted by white-backed planthopper (WBPH) (Sogatella furcifera) in a circulative, propagative, and persistent manner but cannot be transmitted by brown planthopper (BPH) (Nilaparvata lugens) $(21,32)$. WBPH is a typical long-distance migratory pest in East and Southeast Asia. It usually inhabits a rice plant during its nymphal and brachypterous adult stages but it frequently moves among different plants in a field or over long distances after it develops into a macropterous adult. In the disease cycle described by Guo et al. (6), SRBSDV and WBPH overwinter in a warm tropical or subtropical area; then, the viruliferous WBPH adults bring the virus from the south to the north through their migration in early spring. These adults transmit SRBSDV to rice seedlings in the newly colonized areas and lay eggs on them. After hatching, the next generation of WBPH feed on the infected seedlings and a high proportion of them become viruliferous. Their dispersal may lead to a secondary infection of the virus and severe outbreaks of the viral disease.

Rice ragged stunt virus (RRSV) (genus Oryzavirus, family Reoviridae) is vectored by $\mathrm{BPH}$, another long-distance migratory

Corresponding author: G. Zhou; Email address: ghzhou@ scau.edu.cn

http://dx.doi.org/10.1094/PHYTO-08-13-0227-R

(C) 2014 The American Phytopathological Society rice pest closely related to $\mathrm{WBPH}$, but cannot be transmitted by WBPH. This virus was first described in 1977. It also is distributed in eastern and southeastern Asia (18). It was not a serious problem in China because its vector immigrated at the late growth stage of rice when the plants had developed resistance or tolerance to the virus. However, this virus has become more and more common in China during the last several years. It is often detected in rice plants infected with SRBSDV and aggravates the disease symptoms. According to field investigations, SRBSDV might assist RRSV transmission and infection.

In recent years, virus-vector interactions have attracted increased attention. It is now recognized that plant viruses not only can directly affect the development and fecundity of their insect vectors as pathogens (4) but also can modify vector behavior or indirectly influence plant-vector interactions $(3,15-17,20)$. In the literature, there are many examples of the indirect (host plant infection-mediated) and direct (vector infection-caused) influence of viruses on vector behavior and performance, such as vector attraction $(5,17,22)$, settling and feeding $(2,5,24)$, and other life parameters $(2,5)$. In addition, the influence of a plant virus on its vector's transcriptome (30) and (potentially) genome (4) has also been reported. Mauck and colleagues (14) analyzed 55 research papers containing 224 experiments, each of which examined some aspect of a plant virus's influence on vector behavior or performance. Their statistical analysis indicated that most of the results supported the hypothesis that the viral effects on host plant phenotypes and plant-vector interactions depend on the manner of virus transmission. Like other parasites, plant viruses enhance their dissemination by manipulating host plant phenotypes and vector behaviors $(9,11)$.

SRBSDV is an ideal tool for the study of virus-plant-vector interaction. In this study, we tested the patterns of orientation 
preference of macropterous WBPH between infected and healthy rice plants. In addition, to figure out whether SRBSDV infection may enhance transmission and spread of RRSV, the BPH preference between SRBSDV-infected and healthy plants was also tested. Our results provide an insight into the epidemiological mechanisms of SRBSDV spread and SRBSDV/RRSV co-infection.

\section{MATERIALS AND METHODS}

Virus and inoculation of vector. The SRBSDV and RRSV isolates were maintained on a number of rice plants grown in an insect-proof greenhouse in our laboratory. WBPH individuals were reared and propagated on the SRBSDV-infected plants and $\mathrm{BPH}$ individuals on RRSV-infected plants to become viruliferous. The infective insects were used for subsequent viral inoculations.

Reverse-transcription polymerase chain reaction detection. Total RNA extractions from rice leaf tissue or individual insects (WBPH or BPH) were conducted as described by Wang et al. (28), and the extracts were subjected to reverse-transcription polymerase chain reaction (RT-PCR) detection using a One-Step RNA PCR kit (TaKaRa Biotech. Co. Ltd., Dalian, China) following the manufacturer's protocol. The RT-PCR primers for SRBSDV were 5'-CGCGTCATCTCAAACTACAG-3' and 5'TTTGTCAGCATCTAAAGCGC-3' (amplicon size $=682 \mathrm{bp}$ ), and the primers for RRSV were 5'-CGCCGTATCTAACGTTCCAG-3' and 5'-TGCCGCGACATAATCAAC-3' (amplicon size $=397 \mathrm{bp}$ ). The thermal cycling conditions of RT-PCR detection for both of the viruses included $50^{\circ} \mathrm{C}$ for $30 \mathrm{~min}, 94^{\circ} \mathrm{C}$ for $2 \mathrm{~min}$, and 35 cycles of $94^{\circ} \mathrm{C}$ for $30 \mathrm{~s}, 52^{\circ} \mathrm{C}$ for $30 \mathrm{~min}, 72^{\circ} \mathrm{C}$ for $1 \mathrm{~min}$, and $72^{\circ} \mathrm{C}$ for $5 \mathrm{~min}$.

Plant material for orientation preference tests. The rice cultivar used in this study ('Qiuyou 998') was purchased from Guangdong Academy of Agricultural Sciences, Guangzhou, China. Water planting of the rice was conducted according to Yoshida et al. (31). The seed were germinated and sown in a 2-liter beaker $(2.5 \mathrm{~cm}$ in diameter and $25 \mathrm{~cm}$ in height) half filled with a culture solution ( $\mathrm{pH} 4.5$ to 5.0) until the three- or four-leaf seedling stage. A number of seedlings of uniform size were selected and transferred to new beakers, each of which contained $1,600 \mathrm{ml}$ of the culture solution and 10 seedlings. Each rice seedling was inoculated with two third- or fourth-instar WBPH or $\mathrm{BPH}$ nymphs, which were obtained from rearing the vector on the infected plants (as described above). Each beaker was then sealed using a transparent plastic cover with small holes in it, and incubated for $48 \mathrm{~h}$ in an illumination incubator $\left(27^{\circ} \mathrm{C}\right.$, humidity of 60 to $75 \%, 16 \mathrm{~h}$ of light and $8 \mathrm{~h}$ of darkness), followed by a thorough manual removal of the insects. Culturing of the inoculated plants was continued under the same conditions, with the culture solution renewed once per week. A small amount of leaf tissue was collected 15 days after the inoculation and used for total RNA extraction and RT-PCR detection. When the seedlings reached the tillering phase $(\approx 35$ days after the inoculation), RTPCR-confirmed SRBSDV- or RRSV-infected individuals of 30 to $40 \mathrm{~cm}$ were selected for the orientation preference experiments. Healthy individuals, obtained by following the same water culturing method and undergoing a 48-h inoculation with virusfree WBPH or BPH individuals, were selected using the same criteria.

Insects for orientation preference tests. The WBPHs and BPHs, both collected from field rice plants in the suburb of Guangzhou, Guangdong Province, China, were reared on healthy rice plants for three generations in an illumination incubator under to $28^{\circ} \mathrm{C}$. Then, the WBPH nymphs were divided into two groups. One group was transferred to SRBSDV-infected plants and the other to healthy plants. Similarly, groups of BPH nymphs were assigned to RRSV-infected and healthy plants. The next (fourth)-generation macropterous adults were used for the orientation preference tests. After the completion of the tests, the insects from SRBSDV- or RRSV-infected plants were individually examined by RT-PCR. The virus-positive individuals were defined as viruliferous and the negative individuals as nonviruliferous. The WBPH or BPH individuals coming from healthy plants were defined as virus-free.

Host orientation preference tests. WBPHs and BPHs were tested using a dual-choice setup, using a glass Y-tube olfactometer according to the method described by Signoretti et al. (23), with minor modifications. The Y-shaped tube (2-cm inner diameter) consisted of a central tube (13 cm long) and two arms $(10 \mathrm{~cm}$ long, offset by $\left.60^{\circ}\right)$ that connected to a glass odor bottle $(50 \mathrm{~cm}$ in height, 6-cm inner diameter). A threshold line of $3.5 \mathrm{~cm}$ (onethird of the arms' lengths) away from the fork of the Y-tube was marked on both arms. The airflow in the olfactometer (500 $\mathrm{ml} / \mathrm{min}$ ) was calibrated using a flow meter at the end of each arm. The Y-tube was horizontally positioned in an airtight cubic box (70 by 45 by $30 \mathrm{~cm}$ ) lighted by a $30-W$ filament lamp $25 \mathrm{~cm}$ above it. The tested odor sources (i.e., healthy plant, SRBSDVinfected plant, or air) were enclosed in the odor bottles $10 \mathrm{~min}$ prior to the tests to allow the odors to fill the arms. Insects (macropterous adults, starved for $1 \mathrm{~h}$ before being tested) were individually placed in the central tube and allowed to make a choice between two arms. When a planthopper reached the fork of the tube, timing was started. A choice was registered if the insect passed the threshold line on either arm within $10 \mathrm{~min}$ and stayed in the arm for more than $2 \mathrm{~min}$. Otherwise, the insect was considered as having no orientation preference. The two odors at the terminals of the Y-tube were swapped after five insects had been tested. The infection status of the insects was examined by RT-PCR detection after the test. The whole device was rinsed using distilled water, $90 \%$ ethanol, and distilled water again, and heat-dried between manipulations of different treatments. The 15 treatments for host orientation preference tests were designed as follows: (i) virus-free WBPH for healthy plants/air, (ii) virus-free WBPH for SRBSDV-infected plants/air, (iii) virus-free WBPH for healthy plants/SRBSDV-infected plants, (iv) viruliferous WBPH for healthy plants/air, (v) viruliferous WBPH for SRBSDVinfected plants/air, (vi) viruliferous WBPH for healthy plants/ SRBSDV-infected plants, (vii) nonviruliferous WBPH for healthy plants/air, (viii) nonviruliferous WBPH for SRBSDV-infected plants/air, (ix) nonviruliferous WBPH for healthy plants/SRBSDVinfected plants, (x) virus-free BPH for healthy plants/air, (xi) virus-free BPH for SRBSDV-infected plants/air, (xii) virus-free $\mathrm{BPH}$ for healthy plants/SRBSDV-infected plants, (xiii) viruliferous BPH for healthy plants/air, (xiv) viruliferous BPH for SRBSDV-infected plants/air, and (xv) viruliferous BPH for healthy plants/SRBSDV-infected plants (Table 1). We had planned to conduct five replicates for each treatment, with 15 males and 15 females per replicate. However, we could obtain only a limited number of nonviruliferous WBPH individuals for the test (treatments 7 to 9) and, subsequently, we tested 30 males and 30 females in treatment 9 (Table 1).

Data analysis. Statistical analyses of the data obtained from the tests were performed using SPSS 16.0 software. For each treatment, differences in insect orientation preferences between the two odor cues were detected using a $t$ test, and differences in preference of male and female individuals were detected using a $\chi^{2}$ test.

\section{RESULTS}

When faced with the choice between a rice plant and air, the majority of virus-free WBPH individuals preferred the healthy $(64.7 \%)$ and SRBSDV-infected plants $(69.3 \%)$ to air (Table 1). When tested for a preference between the infected and healthy plants, $60.0 \%$ of the individuals preferred the infected plants, which was significantly more than the number $(26.7 \%)$ that were attracted to the healthy plants $(t=7.4536$, df $=4, P=0.0017)$ 
(Fig. 1). No significant quantitative difference was found between the virus-free WBPH male and female individuals responding to the rice plants $\left(\chi^{2}=0.0179\right.$, $\left.\mathrm{df}=1, P=0.11\right)$ (Fig. 1$)$.

When faced with the choice between a rice plant and air, the majority of the viruliferous WBPH individuals preferred the healthy $(71.3 \%)$ and infected plants $(76.7 \%)$ to air (Table 1). When tested for a preference between the infected and healthy plants, $69.3 \%$ of the individuals preferred the healthy plants, significantly more than the number $(17.3 \%)$ that were attracted to the infected plants $(t=6.1377$, df $=4, P=0.0036)$ (Fig. 2). No significant quantitative difference was found between the viruliferous WBPH male and female individuals responding to the rice plants $\left(\chi^{2}=0.0308\right.$, df $\left.=1, P=0.14\right)$ (Fig. 2).

Only a small number of WBPH individuals propagated on the SRBSDV-infected plants remained nonviruliferous (Table 1) because of the high virus acquisition rate of the vector (21). We tested 60 nonviruliferous individuals for a preference between the infected and healthy plants. The results showed that $65.0 \%$ of the

TABLE 1. Rice host selection preference tests of white-backed planthopper (WBPH) and brown planthopper (BPH) ${ }^{\mathrm{a}}$

\begin{tabular}{|c|c|c|c|c|c|c|c|c|c|}
\hline \multirow[b]{2}{*}{ Replicate $^{\text {b }}$} & \multicolumn{3}{|c|}{ Virus-free } & \multicolumn{3}{|c|}{ Viruliferous $^{\mathrm{c}}$} & \multicolumn{3}{|c|}{ Nonviruliferous $^{\mathrm{d}}$} \\
\hline & HP/air & IP/air & HP/IP & HP/air & IP/air & HP/IP & HP/air & IP/air & $\mathrm{HP} / \mathrm{IP}$ \\
\hline \multicolumn{10}{|l|}{ WBPH } \\
\hline 1 & $20 / 4$ & $19 / 7$ & $7 / 17$ & $21 / 4$ & $24 / 3$ & $18 / 9$ & $10 / 3$ & $15 / 4$ & $39 / 13$ \\
\hline 2 & $22 / 2$ & $22 / 3$ & $10 / 17$ & $21 / 1$ & $23 / 3$ & $20 / 6$ & $\ldots$ & $\ldots$ & $\ldots$ \\
\hline 3 & $18 / 5$ & $21 / 7$ & $5 / 20$ & $21 / 3$ & $25 / 1$ & $22 / 1$ & $\ldots$ & $\ldots$ & $\ldots$ \\
\hline 4 & $17 / 9$ & $20 / 4$ & $9 / 18$ & $24 / 1$ & $22 / 3$ & $24 / 2$ & $\ldots$ & $\ldots$ & $\ldots$ \\
\hline 5 & $20 / 6$ & $22 / 3$ & $9 / 18$ & $20 / 7$ & $21 / 1$ & $20 / 8$ & $\ldots$ & $\ldots$ & $\ldots$ \\
\hline Total & 150 & 150 & 150 & 150 & 150 & 150 & 13 & 19 & 60 \\
\hline Average & 19.4/5.2 & $20.8 / 4.8$ & $8.0 / 18.0$ & 21.4/3.2 & 23.0/2.2 & 20.8/5.2 & $\ldots$ & $\ldots$ & $\ldots$ \\
\hline $\mathrm{SE}$ & $0.87 / 1.16$ & $0.58 / 0.92$ & $0.89 / 0.55$ & $0.68 / 1.11$ & $0.71 / 0.49$ & $1.02 / 1.59$ & $\ldots$ & $\ldots$ & $\ldots$ \\
\hline$t$ & 7.2464 & 11.6076 & 7.4536 & 10.9950 & 24.1795 & 6.1377 & $\ldots$ & $\ldots$ & $\ldots$ \\
\hline$P$ & 0.0019 & 0.0003 & 0.0017 & 0.0004 & 0.0001 & 0.0036 & $\ldots$ & $\ldots$ & $\ldots$ \\
\hline \multicolumn{10}{|l|}{$\mathrm{BPH}$} \\
\hline 1 & $23 / 1$ & $22 / 2$ & $18 / 6$ & $18 / 9$ & $16 / 9$ & $7 / 16$ & $\ldots$ & $\ldots$ & $\ldots$ \\
\hline 2 & $21 / 4$ & $21 / 4$ & $15 / 9$ & $19 / 6$ & $19 / 6$ & $8 / 17$ & $\ldots$ & $\ldots$ & $\ldots$ \\
\hline 3 & $23 / 3$ & $21 / 3$ & $18 / 9$ & $20 / 7$ & $17 / 7$ & $4 / 18$ & $\ldots$ & $\ldots$ & $\ldots$ \\
\hline 4 & $22 / 5$ & $17 / 5$ & $17 / 7$ & $19 / 4$ & $16 / 10$ & $9 / 19$ & $\ldots$ & $\ldots$ & $\ldots$ \\
\hline 5 & $22 / 3$ & $21 / 4$ & $16 / 8$ & $19 / 7$ & $17 / 6$ & $6 / 17$ & $\ldots$ & $\ldots$ & $\ldots$ \\
\hline Total & 150 & 150 & 150 & 150 & 150 & 150 & $\ldots$ & $\ldots$ & $\ldots$ \\
\hline Average & $22.2 / 3.2$ & 20.4/3.6 & $16.8 / 7.8$ & 19.0/6.6 & 17.0/7.6 & $6.8 / 17.4$ & $\ldots$ & $\ldots$ & $\ldots$ \\
\hline SE & $0.37 / 0.66$ & $0.87 / 0.51$ & $0.58 / 0.58$ & $0.32 / 0.81$ & $0.55 / 0.81$ & $0.86 / 0.51$ & $\ldots$ & $\ldots$ & $\ldots$ \\
\hline$t$ & 20.0278 & 12.7360 & 9.0000 & 12.6557 & 7.2958 & 11.4303 & $\ldots$ & $\ldots$ & $\ldots$ \\
\hline$P$ & 0.0001 & 0.0002 & 0.0008 & 0.0002 & 0.0019 & 0.0003 & $\ldots$ & $\ldots$ & $\ldots$ \\
\hline
\end{tabular}

${ }^{a} \mathrm{HP}=$ healthy plant and IP = infected plant (SRBSDV- or RRSV-infected).

${ }^{\mathrm{b}}$ Total $=$ total planthoppers, including individuals that did not show a preference in dual-choice tests, and SE $=$ standard error.

c Southern rice black-streaked dwarf virus (SRBSDV)-carrying WBPH or Rice ragged stunt virus (RRSV)-carrying BPH.

${ }^{\mathrm{d}}$ WBPH without SRBSDV after feeding on infected plants.

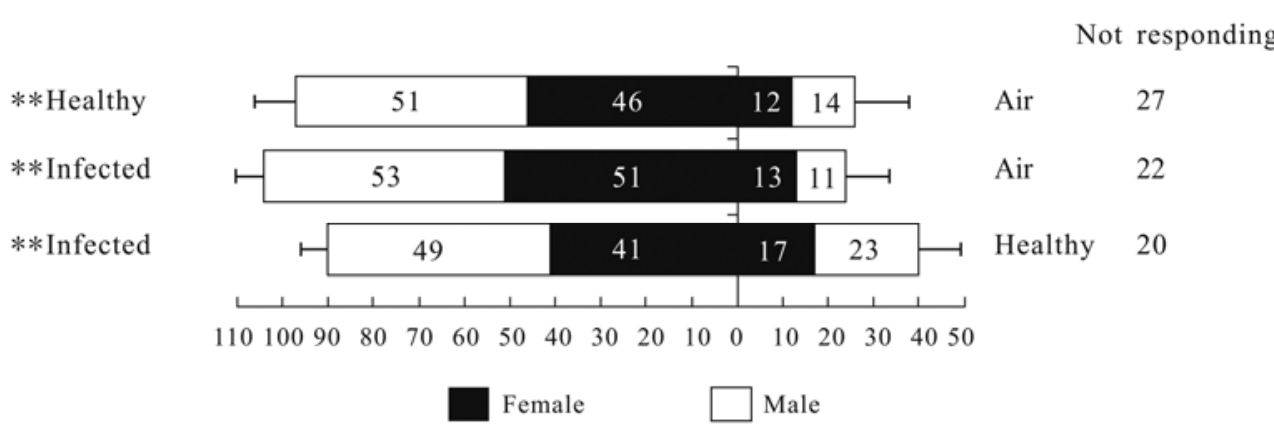

Fig. 1. Responses of virus-free white-backed planthoppers (WBPHs) to odor cues in the dual-choice olfactometer. Double asterisks indicate very significant difference $(t$ test, $P<0.01)$. Numbers of individuals that responded or did not respond are given.

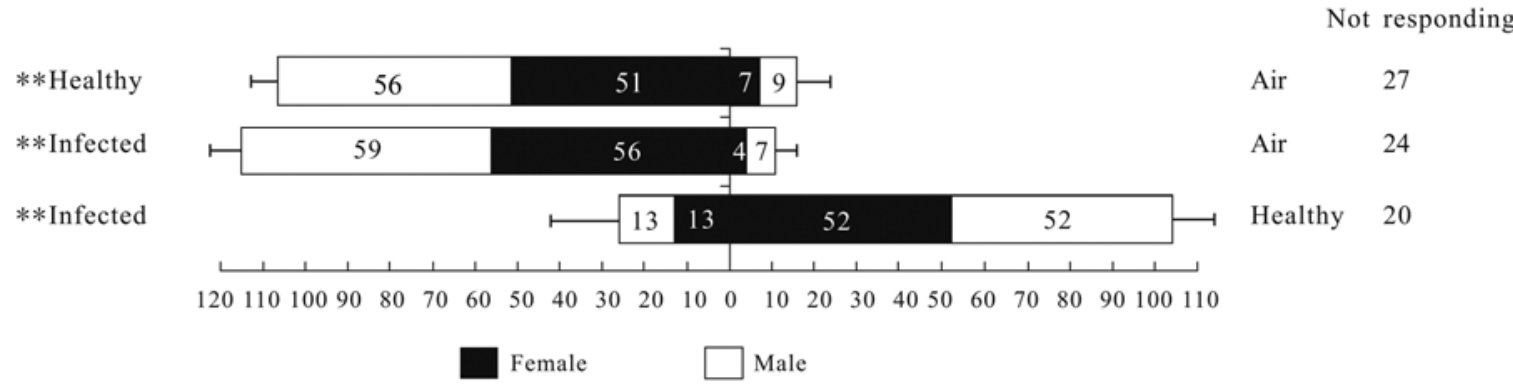

Fig. 2. Responses of Southern rice black-streaked dwarf virus (SRBSDV)-carrying white-backed planthoppers (WBPHs) to odor cues in the dual-choice olfactometer. Double asterisks indicate very significant difference $(t$ test, $P<0.01)$. Numbers of individuals that responded or did not respond are given. 
individuals preferred the healthy plants, three times more than those $(21.7 \%)$ that were attracted to the infected plants (Table 1). Nearly equal numbers of the nonviruliferous WBPH male and female individuals responded to the rice plants. In all, 6 males and 7 females chose infected plants and 17 males and 22 females chose healthy plants.

When faced with the choice between a rice plant and air, the majority of the virus-free BPH individuals preferred the healthy $(74.0 \%)$ and infected plants $(68.0 \%)$ to air (Table 1$)$. When tested for a preference between the infected and healthy plants, $56.0 \%$ of the virus-free BPH individuals preferred the healthy plants, significantly more than the number $(26.0 \%)$ that were attracted to the SRBSDV-infected plants $(t=9.00, \mathrm{df}=4, P=0.0008$ ) (Fig. $3)$. No significant quantitative difference was found between the male and female BPHs responding to the rice plants $\left(\chi^{2}=0.1854\right.$, df $=1, P=0.33$ ) (Fig. 3).

When faced with the choice between a rice plant and air, the majority of the RRSV-carrying BPH individuals preferred the healthy (63.3\%) and SRBSDV-infected plants (56.7\%) to air (Table 1). When tested for a preference between the infected and healthy plants, $58.0 \%$ of the RRSV-carrying individuals preferred the SRBSDV-infected plants, significantly more than the number $(22.7 \%)$ that were attracted to the healthy plants $(t=11.43, \mathrm{df}=$ $4, P=0.0003$ ) (Fig. 4). No significant quantitative difference was found between the male and female BPHs responding to the rice plants $\left(\chi^{2}=0.0670, \mathrm{df}=1, P=0.20\right)$ (Fig. 4).

\section{DISCUSSION}

Our results indicated that SRBSDV infection altered the attractiveness of rice plants to both the vector (WBPH) of the virus and the nonvector insect (BPH). SRBSDV-infected plants were more attractive to virus-free WBPH individuals but less to the viruliferous ones, whereas healthy plants were more attractive to the viruliferous but less to the virus-free individuals (Figs. 1 and 2). There are many documented examples of enhanced attractiveness to insect vectors of virus-infected plant hosts relative to uninfected plant hosts $(1,12,14-17,19)$. However, to date, there is only one study that has investigated host preferences of both virus-free and viruliferous vectors at the same time. Ingwell et al. (9) studied Barley yellow dwarf virus (BYDV), a persistently transmitted circulative nonpropagative plant virus, and its vector aphid, Rhopalosiphum padi, and found that virus-free (termed noninfective) aphids preferred BYDV-infected wheat plants to healthy plants, whereas the viruliferous (termed infective) preferred uninfected plants. Thus, they proposed the vector manipulation hypothesis (VMH), a general hypothesis to explain the evolution of plant pathogens' strategies to promote their dissemination to new hosts. The hypothesis states that host orientation behavior of the vector can, or can be changed by the virus to, promote transmission and spread of the virus (9). A virus-free vector with a preference for an infected host would enhance viral acquisition by the vector and a viruliferous vector with a preference for an uninfected host would enhance viral transmission and dispersal. In this study, we report an additional case of a plant virus modifying the host selection behavior of its vector, and the first case of this involving a persistently transmitted, circulative, propagative plant virus.

SRBSDV is a persistently transmitted plant virus. To become viruliferous, WBPH needs enough time to acquire the virus by feeding on the virus-infected plants (5 to $30 \mathrm{~min}$ ) and, subsequently, to allow the virus to circulate and propagate in its body (6 to 14 days) (21). Given the significantly decreased longevity (less than 15 days at $25^{\circ} \mathrm{C}$ ) of viruliferous WBPH adults (25), they have a very short remaining life after becoming viruliferous and, therefore, have limited opportunities for viral transmission. If viruliferous WBPH individuals should select infected plants and lay eggs on them, they would contribute a certain amount of efficient next-generation vectors with high viral-transmission ability and excellent mobility (macropterous adults). However, Tu et al. (25) revealed that, compared with the virus-free individuals, viruliferous WBPHs have significantly decreased oviposition amounts and, subsequently, the contribution they could make to viral transmission by the next-generation vectors (their offspring)

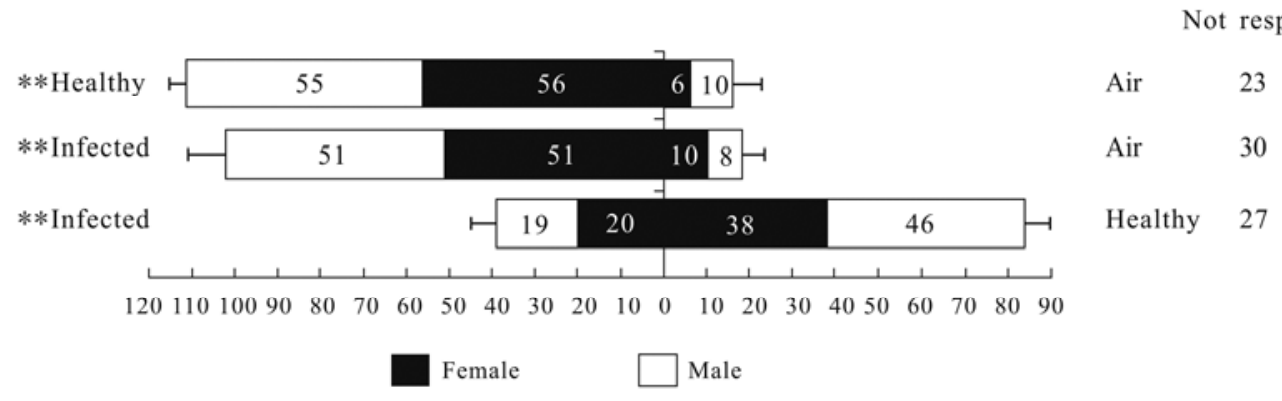

Fig. 3. Responses of virus-free brown planthoppers (BPHs) to odor cues in the dual-choice olfactometer. Double asterisks indicate very significant difference $(t$ test, $P<0.01)$. Numbers of individuals that responded or did not respond are given.

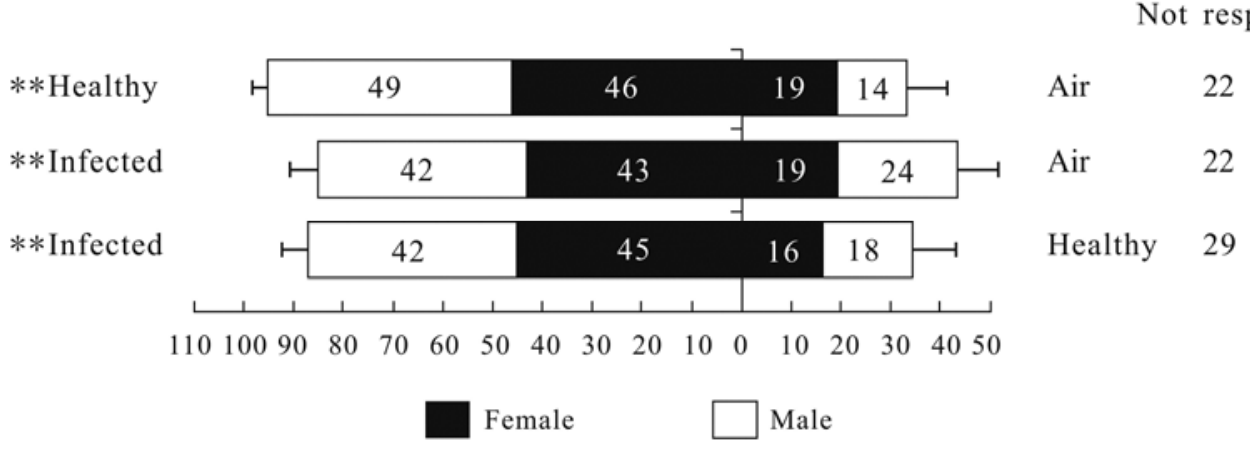

Fig. 4. Responses of Rice ragged stunt virus (RRSV)-carrying brown planthoppers (BPHs) to odor cues in the dual-choice olfactometer. Double asterisks indicate very significant difference $(t$ test, $P<0.01)$. Numbers of individuals that responded or did not respond are given. 
would be very low. It is suggested that, for viruliferous WBPH, the avoidance of infected plants may avoid wasting the time and opportunity to transmit the virus. In this study, the increased attraction of virus-free WBPH and the reduced attraction of the viruliferous WBPH to SRBSDV-infected plants are both consistent with the need of the plant virus to expand its distribution by manipulating plant host-insect vector interactions. The SRBSDVWBPH interactions revealed in this study may account for the serious field occurrence of the virus and its fast spread in East and Southeast Asia since it was first identified in 2001.

In addition to the preference orientation tests on virus-free and viruliferous vectors, we also investigated the host selection preference of nonviruliferous WBPH. These were WBPH individuals that fed on the SRBSDV-infected plants but did not acquire the virus. Although we could not obtain enough nonviruliferous WBPH for a five-replicate experiment, our results are reliable because they were derived from as many as 60 nonviruliferous individuals, which were used in a single test to detect a host selection preference between infected and healthy plants. Nonviruliferous WBPHs, like the viruliferous but unlike the virus-free ones, were more attracted to healthy plants than to infected ones (Table 1). This interesting finding is inconsistent with the VMH proposed by Ingwell et al. (9), because the preference of a nonviruliferous vector for healthy plants cannot contribute to enhance virus spread and transmission. Compared with healthy plants, virus-infected plants can be inferior hosts for some insect vectors (16). Tu et al. (25) reported that SRBSDV-infected rice plants were generally harmful to the development and fecundity of WBPH. Virus-free insect vectors, deceptively attracted by the volatile organic compounds (VOCs) emitted from an infected host, may acquire the virus but frequently quickly disperse as if responding to contact or gustatory cues $(14,15)$. Insects have the ability to learn and remember, and there is evidence that they can recall certain odors that were not innately recognized (8). Webster et al. (29) proposed that insects preferentially respond to volatile odors that they remember from their natal habitats when the odor source (i.e., the plant) is easy to reach, or innately respond to the same odors when the precise host location is unavailable to them. Although this hypothesis can explain why both viruliferous and nonviruliferous WBPHs preferred the odors from healthy plants (in our Y-tube olfactometer tests, the plants are beyond the insect's reach), it cannot explain why virus-free WBPHs preferred infected plants. Our hypothesis is that the WBPH individuals with SRBSDV-infected plant-feeding experience were able to remember the unfavorable quality of the infected hosts and distinguish them via volatile cues, resulting in their preference for healthy plants. Studies on host selection preferences of other vectors that have remained nonviruliferous after feeding upon diseased plants will provide further insights into this phenomenon and its implications.

$\mathrm{BPH}$ (a nonvector of SRBSDV), another rice planthopper, was found to prefer uninfected rice plants to the SRBSDV-infected plants when it was virus-free; however, it preferred SRBSDVinfected plants when it was carrying RRSV (Figs. 3 and 4). Our result from virus-free $\mathrm{BPH}$ is consistent with previous results $(16,26)$, suggesting that the VOCs of a virus-infected host may decrease a nonvector's preference for the plant. To our knowledge, the result from the RRSV-carrying BPH represents the first case in which a vector carrying a plant virus preferred a host plant infected with another virus over a healthy plant. This suggests that a virus (RRSV) may modify the behaviors of its vector (BPH) or a virus (SRBSDV) may modify the behaviors of a nonvector $(\mathrm{BPH})$ to promote co-infection of host plants by more than one virus. Indeed, our field surveys have often found mixed infections of SRBSDV and RRSV in areas in Guangdong Province, China (unpublished data). Furthermore, a small proportion (3 to 5\%) of a third rice planthopper, small brown planthopper (SBPH) (Laodelphax striatellus), which is the major vector of Rice black- streaked dwarf virus (RBSDV), can acquire SRBSDV from infected rice plants but cannot transmit the virus because of a restriction of viral movement from midgut into hemolymph $(10,21,32)$. If our proposed pattern is correct, we predict that the behavior of this noncompatible vector will be similar to the nonvector $\mathrm{BPH}$ in terms of host selection preference between uninfected and SRBSDV-infected rice plants. Thus, the virus-free SBPH will have a preference for healthy rice plants and RBSDVcarrying SBPH for SRBSDV-infected ones, which might lead to co-infection of RBSDV and SRBSDV in the field. However, many questions need to be answered. For example, are virusinduced rice-planthopper interactions vector specific? How can an RRSV-carrying BPH be attracted by an SRBSDV-infected plant? Is it RRSV, SRBSDV, or both together that alters the host selection preference of BPH when it carries RRSV? What chemical, biological, or physiological processes; what molecular mechanisms; and what genes are involved in rice virus-rice-rice planthopper interactions? Further investigations will be necessary to improve our knowledge regarding the complex interactions and coevolution of similar pathosystems.

\section{ACKNOWLEDGMENTS}

This work was supported by the National Natural Science Foundation of China (31272012 and 31071661), the International Science \& Technology Cooperation Program of China (2012DFA31220), and the Special Fund for Agro-scientific Research in the Public Interest, China (201003031 and 201303021). We thank J. Xue for maintaining plants in the greenhouse and $\mathrm{Z}$. Tu for experimental assistance and commenting on the manuscript.

\section{LITERATURE CITED}

1. Alvarez, A. E., Garzo, E., Verbeek, M., Vosman, B., Dicke, M., and Tjallingii, W. F. 2007. Infection of potato plants with potato leafroll virus changes attraction and feeding behaviour of Myzus persicae. Entomol. Exp. Appl. 125:135-144.

2. Boquel, S., Delayen, C., Couty, A., Giordanengo, P., and Ameline, A. 2012. Modulation of aphid vector activity by Potato virus $Y$ on in vitro potato plants. Plant Dis. 96:82-86.

3. Bosque-Perez, N. A., and Eigenbrode, S. D. 2011. The influence of virusinduced changes in plants on aphid vectors: insights from luteovirus pathosystems. Virus Res. 159:201-205.

4. Czosnek, H., and Ghanim, M. 2012. Back to basics: are begomoviruses whitefly pathogens? J. Integr. Agric. 11:225-234.

5. Fereres, A., and Moreno, A. 2009. Behavioural aspects influencing plant virus transmission by homopteran insects. Virus Res. 141:158-168.

6. Guo, R., Zhou, G., and Zhang, S. 2010. Character of rice southern blackstreaked disease and its control strategy (in Chinese). China Plant Prot. 30:17-20.

7. Hoang, A. T., Zhang, H. M., Yang, J., Chen, J. P., Hébrard, E., Zhou, G. H., Vinh, V. N., and Cheng, J. A. 2011. Identification, characterization, and distribution of Southern rice black-streaked dwarf virus in Vietnam. Plant Dis. 95:1063-1069.

8. Huigens, M. E., Pashalidou, F. G., Qian, M. H., Bukovinszky, T., Smid, H. M., van Loon, J. J., Dicke, M., and Fatouros, N. E. 2009. Hitch-hiking parasitic wasp learns to exploit butterfly antiaphrodisiac. Proc. Natl. Acad. Sci. USA 106:820-825.

9. Ingwell, L. L., Eigenbrode, S. D., and Bosque-Perez, N. A. 2012. Plant viruses alter insect behavior to enhance their spread. Sci. Rep. 2:1-6.

10. Jia, D. S., Chen, H. Y., Mao, Q. Z., Liu, Q. F., and Wei, T. Y. 2012. Restriction of viral dissemination from the midgut determines incompetence of small brown planthopper as a vector of Southern rice blackstreaked dwarf virus. Virus Res. 167:404-408.

11. Lefevre, T., and Thomas, F. 2008. Behind the scene, something else is pulling the strings: emphasizing parasitic manipulation in vector-borne diseases. Infect. Genet. Evol. 8:504-519.

12. Liu, B., Preisser, C. L., and Chu, D. 2013. Multiple forms of vector manipulation by a plant-infecting virus: Bemisia tabaci and Tomato yellow leaf curl virus. J. Virol. 87:4929-4937.

13. Matsukura, K., Towata, T., Sakai, J., Onuki, M., Okuda, M., and Matsumura, M. 2013. Dynamics of Southern rice black-streaked dwarf virus in rice and implication for virus acquisition. Phytopathology 103:509-512.

14. Mauck, K. E., Bosque-Perez, N. A., Eigenbrode, S. D., De Moraes, C. M., 
and Mescher, M. C. 2012. Transmission mechanisms shape pathogen effects on host-vector interactions: evidence from plant viruses. Funct. Ecol. 26:1162-1175.

15. Mauck, K. E., De Moraes, C. M., and Mescher, M. C. 2010. Deceptive chemical signals induced by a plant virus attract insect vectors to inferior hosts. Proc. Natl. Acad. Sci. USA 107:3600-3605.

16. Mauck, K. E., De Moraes, C. M., and Mescher, M. C. 2010. Effects of Cucumber mosaic virus infection on vector and non-vector herbivores of squash. Commun. Integr. Biol. 3:579-582.

17. McMenemy, L. S., Hartley, S. E., MacFarlane, S. A., Karley, A. J., Shepherd, T., and Johnson, S. N. 2012. Raspberry viruses manipulate the behaviour of their insect vectors. Entomol. Exp. Appl. 144:56-68.

18. Milne, R. G., Boccardo G., and Ling K. C. 1982. Rice ragged stunt virus. CMI/AAB Descriptions of Plant Viruses. No. 248.

19. Ng, J. C. K., and Falk, B. W. 2006. Virus-vector interactions mediating nonpersistent and semipersistent transmission of plant viruses. Annu. Rev. Phytopathol. 44:183-212.

20. Oluwafemi, S., Bruce, T., Pickett, J.A., Ton, J., and Birkett, M. A. 2011. Behavioral responses of the leafhopper, Cicadulina storeyi China, a major vector of Maize streak virus, to volatile cues from intact and leafhopperdamaged maize. J. Chem. Ecol. 37:40-48.

21. Pu, L., Xie, G., Ji, C., Ling, B., Zhang, M., Xu, D., and Zhou, G. 2012. Transmission characteristics of Southern rice black-streaked dwarf virus by rice planthoppers. Crop Prot. 41:71-76.

22. Shapiro, L., De Moraes, C. M., Stephenson, A. G., and Mescher, M. C. 2012. Pathogen effects on vegetative and floral odours mediate vector attraction and host exposure in a complex pathosystem. Ecol. Lett. 15:1430-1438.

23. Signoretti, A., Penaflor, M., Moreira, L., Noronha, N. C., and Bento, J. 2012. Diurnal and nocturnal herbivore induction on maize elicit different innate response of the fall armyworm parasitoid, Campoletis flavicincta. J. Pestic. Sci. 85:101-107.

24. Stafford, C. A., Walker, G. P., and Ullman, D. E. 2011. Infection with a plant virus modifies vector feeding behavior. Proc. Natl. Acad. Sci. USA. 108:9350-9355.

25. Tu, Z., Ling, B., Xu, D. L., Zhang, M. X., and Zhou, G. H. 2013. Effects of Southern rice black-streaked dwarf virus on the development and fecundity of its vector, Sogatella furcifera. Virol. J. 10:145.

26. van Molken, T., de Caluwe, H., Hordijk, C. A., Leon-Reyes, A., Snoeren, T., van Dam, N. M., and Stuefer, J. F. 2012. Virus infection decreases the attractiveness of white clover plants for a non-vectoring herbivore. Oecologia 170:433-444.

27. Wang, Q., Yang, J., Zhou, G. H., Zhang, H. M., Chen, J. P., and Adams, M. J. 2010. The complete genome sequence of two isolates of Southern rice black-streaked dwarf virus, a new member of the genus Fijivirus. J. Phytopathol. 158:733-737.

28. Wang, Q., Zhou, G. H., and Zhang, S. G. 2012. Detection of Southern rice black-streaked dwarf virus using one-step dual RT-PCR. Acta Phytopathol. Sin. 42:84-87. (In Chinese)

29. Webster, B., Qvarfordt, E., Olsson, U., and Glinwood, R. 2012. Different roles for innate and learnt behavioral responses to odors in insect host location. Behav. Ecol. 3:366-372.

30. Xu, Y., Zhou, W. W., Zhou, Y. J., Wu, J. X., and Zhou, X. P. 2012. Transcriptome and comparative gene expression analysis of Sogatella furcifera (Horvath) in response to Southern rice black-streaked dwarf virus. PLoS One 7:e36238.

31. Yoshida, S., Forno, D. A., and Gomez, K. A. 1976. Pages 61-64 in: Laboratory Manual for Physiological Studies of Rice, 3rd ed. International Rice Research Institute, Manila, Philippines.

32. Zhou, G. H., Wen, J. J., Cai, D. J., Li, P., Xu, D. L., and Zhang, S. G. 2008. Southern rice black-streaked dwarf virus: a new proposed Fijivirus species in the family Reoviridae. Chin. Sci. Bull. 53:3677-3685.

33. Zhou, G. H., Xu, D. L., and Li, H. P. 2004. Identification of rice black streaked dwarf virus infecting rice in Guangdong (in Chinese). Pages 210212 in: Proc. Conf. Chin. Plant Pathol. Y. L. Peng, ed. Agricultural Scientech Press, Beijing. 